Ana Podvršič

\title{
O epistemološki izbiri: Gypsy Studies kot slovenska državotvorna veda
}

Ključne besede: Romi, akademski diskurz, kulturni študiji, neoliberalizem

Lani sta Slovenijo obiskala francoska socialna antropologa, ki proučujeta Rome, natančneje, Rome Kalderaš, Rome Manouš in Gabore. Kot predavatelja sta sodelovala pri okrogli mizi, ki je bila organizirana v sklopu projekta Maribor 2012: Evropska prestolnica kulture. Organizatorji dogodka so gosta vztrajno naslavljali kot romologa; to ju je sprva morda še zabavalo, ko pa so ju predstavili tudi kot folklorista, se je njuna dobrovoljnost spreobrnila v ogorčenje. Zdi se, da prireditelji okrogle mize niso razumeli srži nesporazuma - kako pa naj se imenujejo raziskovalci, ki se ukvarjajo $z$ Romi, če ne romologi? Raziskovalca sta tako svoje predavanje začela s pojasnilom, da vede ne določa njen predmet, ampak njena metoda, epistemični horizont in perspektiva raziskovanja - spoznavni predmet je namreč šele produkt spoznavnega procesa in ne samoumevna danost.

Ta dogodek nas je spodbudil k razmisleku o konceptualnem aparatu, s katerim naj družboslovne vede, v našem primeru sociologija, analizirajo družbeno realnost. Zanima nas, ali in kako specifičen kontekst institucionalizacije sociologije kot družbene vede (Wallerstein, 2006, 11; Močnik, 2009, 452-455) določa njeno perspektivo, ki bi lahko pojasnila in ne le opisala družbeno kompleksnost. Natančneje, zanima nas, ali lahko raziskovalec neposredno zaupa temu, kar se mu kaže kot družbena realnost, ali pa ta nemara zahteva nekakšno drugotno obdelavo, ki znanstveno početje loči od samoumevnega oziroma ideološkega govora.

$\mathrm{Na}$ to vprašanje bomo poskušali odgovoriti s pomočjo analize tiste slovenske vednostne produkcije, predvsem sociološke, ki proučuje, kot sama pravi, Rome. Te študije so namreč izjemno zgovorne $\mathrm{z}$ gledišča kompleksnega, a sistematiziranega odnosa med spremembami družbene realnosti in akademskim diskurzom. Obenem menimo, da slovenske razprave o Romih spremlja svojevrsten paradoks: Romi so danes hkrati na margini in v samem središču slovenskega znanstvenega interesa. Opažamo tudi, da kljub veliki medijski pozornosti o skupinah, ki si pravijo Romi, ne vemo veliko. 


\section{Kulturni študiii kot podlaga prevladujočih analiz Romov}

Romi so iz politične in akademske nevidnosti izstopili v specifičnem zgodovinskem trenutku. S propadom sistemov realnega socializma in procesom pridruževanja bivših socialističnih držav Evropski Uniji (EU) so romske skupine, ki so dotlej zanimale kvečjemu romantične zanesenjake in asimilacijske ekstremiste, vstopile $\mathrm{v}$ središče evropskega družbenega dogajanja. $\mathrm{K}$ temu je veliko prispevalo pravno priznanje Romov kot posebne evropske etnične manjšine, saj so te skupine s tem postale predmet akademskega mainstreama (Asséo, 2012, 28). Lahko bi celo rekli, da se podobno kakor »ciganska politika « prve polovice 20. stoletja, ki je izhajala iz tedanje vednosti o Romih, da bi opravičila svoje rasistično-biologistične posege, tudi današnja politika, ki poskuša rešiti pereče »romsko vprašanje«, opira na vplivno mednarodno in lokalno znanstveno delovanje, ki pravzaprav vse bolj spominja na ekspertno početje za potrebe evropskih in mednarodnih institucij, ki se opira zlasti na konceptualni okvir kulturnih študijev $^{1}$ in identitetnega diskurza (Olivera, 2012, 41).

Vznik kulturnih tematik in identitetnega diskurza je del širšega prevrata $\mathrm{v}$ družboslovju in humanistiki, ki se je zgodil na prehodu iz sedemdesetih $\mathrm{v}$ osemdeseta leta prejšnjega stoletja, ko so si kulturni študiji skupaj s sestrskimi postkolonialnimi študiji prisvojili proučevanje družbenosti (prim. Friedman, 2000, 187; Breznik, 2009, 28). Ti študiji naj bi ponudili najprimernejšo razlago procesov, ki zaznamujeta svetovno prizorišče v zadnjih petdesetih letih: pojava gibanj, ki si prizadevajo za priznanje pravic različnih identitetnih in kulturnih skupin, in $t$. $i$. globalizacije.

Medtem ko so tradicionalna protisistemska gibanja zastavljala predvsem vprašanja državnih oblasti in struktur ter poudarjala delavsko razsežnost, politično prizorišče od maja '68 zaznamuje predvsem boj proti diskriminaciji in rasizmu. Ta se kaže bodisi v bojih različnih "manjšinskih « skupin bodisi v prevladi identitetnih tematik v družboslovju (Wallerstein, 2006, 112-113). Nova politično-vednostna praksa je prispevala tudi k preobratu v proučevanju romskih skupin v sedemdesetih letih prejšnjega stoletja. Sociologi so se odtlej vse bolj posvečali »romskim politikam« in socialnim spremembam ter se celo politično angažirali (Janko Spreizer, 2002: 76). Obenem so na prvem Svetovnem romskem kongresu v Londonu leta 1971 določili, da se namesto slabšalnega izraza »Cigan «² za splošno etnično poimenovanje uporablja

1 Kakor večina družboslovnih področij so tudi kulturni študiji zaznamovani s številnimi notranjimi polemikami. Tu problematiziramo predvsem tiste procese, ki so zaznamovali razvoj prevladujočih študij o Romih v evropskem prostoru v zadnjih dvajsetih letih in ki se prepletajo s politiko priznanja manjšinskih pravic.

2 Italijanski socialni antropolog Piasere (1994) opozarja, da je zamenjava pojma Cigan s pojmom Rom semantično reduktivna: niso vsi ljudje, ki se imenujejo Cigani, Romi. 
leksem »Rom «, ki so ga nato prevzele različne mednarodne institucije (OZN, EU) in države, pa tudi slovenska znanstvena govorica.

Nenaden vznik identitetnih tematik naj bi bil posledica t. i. globalizacije, ki naj bi skupaj z razpadom kolonialnih imperijev omogočila prosti pretok kulturnih idej, dobrin in posameznikov ter prispevala $\mathrm{k}$ oblikovanju multikulturnih in hibridnih družb. Ta globalizacija seveda ni proizvedla novih kultur, ampak je le omogočila njihov ponoven preporod s propadom kolonialnih imperijev in odpiranjem meja nacionalnih držav. Odtlej naj bi bila družbena realnost v nenehnem transu - da bi prekinile s starimi kategorijami lokaliziranja, teorije multikulturne družbe predpono trans pritaknejo na vse, kar naj bi poprej tvorilo zaprt sistem: pojmi, kakršni so trans-lokalno, trans-nacionalno, in trans-kulturno, poudarjajo to novo prepustnost slehernih meja (Friedman, 2000, 194).

Ti družbeni transformaciji sta utrdili prepričanje o ekonomskem redukcionizmu tedanjih družboslovnih teorij, ki naj ne bi videle, da sta osrednja družbena realnost zdaj kultura in identiteta, saj poleg razredne stratifikacije individualno identiteto pogojujejo tudi spolna, medgeneracijska, religiozna, kulturna in etnična stratifikacija. Tako naj bi koncept identitete $\mathrm{v}$ nasprotju $\mathrm{z}$ redukcionističnim konceptom razreda zajel vse razsežnosti individua in skupaj $\mathrm{z}$ identitetno politiko celoviteje zgrabil kompleksnost človekovega obstoja, s tem pa predstavljal večji emancipatorni potencial. Kultura naj bi tako postala osnovno prizorišče družbenih bojev - konflikti med skupinami naj ne bi več potekali na podlagi razredne delitve, temveč glede na kulturne razlike (Meiksins Wood, 1995, 238-255).

Ob tem se zastavlja vprašanje, kako naj ta nova zmes raznovrstnih kulturnih pomenov, ki jih navsezadnje druži le njihov dinamični značaj, sobiva. Mehanizem t. i. miroljubne širitve družb in vezivo multikulturne družbe naj bi predstavljalo manjšinsko pravo, ki naj bi skrbelo za ohranjanje kulturnih značilnosti, odločilnih za neko skupino (Asséo, 2012, 28). To početje, ki dejansko institucionalizira esencializem, ${ }^{3}$ pa je le na videz $\mathrm{v}$ protislovju $\mathrm{z}$ multikulturno držo. Razvoj hibridne oziroma multikulturne družbe naj bi namreč zavirala prav nacionalna država, ki naj bi kot homogena enota s svojimi ozemeljskimi mejami in asimilacijsko politiko izključevala oziroma onemogočala razvoj vsega, kar je drugačno. A da bi sploh lahko govorili o nacionalni »čistosti« oziroma etnični homogenosti, moramo državo najprej zreducirati na enotno kulturo, njeno ljudstvo pa na kulturne klone, se pravi na identične posameznike. Multikulturna družba je torej $\mathrm{v}$ tem horizontu le seštevek posameznih homogenih kultur, s čimer koketira z rasno ideologijo (Friedman, 2010, 193-94).

3 Za »teroristično razsežnost « politike priznavanja kolektivnih pravic gl. Močnik $(1999,105)$. 


\section{Iz ekonomskega determinizma $v$ kulturnega}

Zdi se, da se je uveljavljeni kulturalizem, ki, ko gre za naš spoznavni predmet, niha med esencialističnim oziroma organicističnim kulturalizmom in konstruktivizmom (Asséo, 2012, 33), ujel v zanko ideologije pravno-politične institucije kapitalističnega sistema, ki odnose med individui prikazuje kot odnose enakosti in svobodnega delovanja. To velja na primer za študije, ki obstoječe državne institucije opozarjajo na (ne)korektno in (ne)diskriminatorno (medijsko) poročanje o t. i. etničnih in deprivilegiranih manjšinah, stanje pa želijo izboljšati s pozivi k novim pravnim regulacijam. Vendar se pravne določbe oziroma členi kazenskega zakonika namesto s spremembami realnih družbenih razmerij ukvarjajo s prepovedjo uporabe specifičnega izraza, kakršen je »Cigan«, pri čemer ostane njegova ideološka vsebina nedotaknjena. Četudi izraz spremenimo in predpišemo uporabo novega, politično korektnega, bo, kot poudari Lev Centrih $(2007,38)$, ideološka vsebina prvotnega izraza nedvomno hitro našla novo materialno eksistenco in, če bo treba, tudi spremenila formo, saj njeni materialni pogoji, ki izhajajo iz realnih razmerij družbene neenakosti, ostajajo nespremenjeni.

Problem identitetnih diskurzov je namreč v tem, da ne tematizirajo zgodovinskih možnosti obstoja "svobodnega individua" oziroma "civilne družbe» in procesa vzpostavljanja družbenih sfer ekonomije, politike in kulture. Zato niso sposobni misliti njihove medsebojne prepletenosti in določenosti ter zlasti pogojenosti politične in kulturne sfere $\mathrm{z}$ obstojem specifičnega, kapitalističnega produkcijskega načina:

[V] družbeni produkciji [...] stopajo ljudje v določene, nujne, od njihove volje neodvisne odnose - v produkcijske odnose, ki ustrezajo določeni razvojni stopnji njihovih materialnih produktivnih sil. Celota teh produkcijskih odnosov sestavlja ekonomsko strukturo družbe, realno osnovo, ki se na njej dviga pravna in politična vrhnja stavba in ki ji ustrezajo določene oblike družbene zavesti. Način produkcije materialnega življenja določa socialni, politični in duhovni proces življenja nasploh (Marx, 1979, 105).

Potemtakem ekonomska sfera družbe skupaj s politiko in pravom, ki legitimirata obstoječa produkcijska razmerja, določa, kako se bo organizirala družbena struktura in $\mathrm{z}$ njo vse druge družbene sfere. Zato kulturalisti padejo na izpitu takoj, ko jih postavimo pred vprašanje razredne razlike. Ker to razliko določajo odnosi v sferi produkcije, ki pa so strukturni odnosi neenakosti, je ne moremo izenačiti s kulturnimi in drugimi identitetnimi razlikami, četudi je res, da različne identitete zavzamejo različne strukturne položaje in da so različno situirane v odnosu do vladajoče strukture, tj. do kapitalističnega svetovnega sistema. Kljub temu pa identitetni boji v ničemer ne 
ogrožajo obstoja kapitalizma, medtem ko bi odprava razredne delitve pomenila prav konec obstoječega družbenega sistema (Meiksins Wood, 1995, 270).

Kulturni študiji lahko govorijo o kulturnem prevratu zato, ker so se postavili na gledišče najbogatejših in višjega srednjega razreda. Nedavne družbene transformacije zagotovo zadevajo celotno svetovno prebivalstvo, a ne tako, kakor se kaže njim. Globalizacija pomeni le odpiranje meja za prosti pretok blaga in kapitala, ne pa tudi dela. Gre za proces postopne liberalizacije držav pod taktirko neoliberalizma, ki ni proizvedel kopice izključenih manjšin, temveč kvečjemu prispeval k vsesplošni proletarizaciji svetovnega prebivalstva, četudi se ta ne odvija povsod z hitrostjo, še manj pa pod istimi regulativi (Wallerstein, 2006, 114). ${ }^{4}$ Podobno tudi nedavni obrat $\mathrm{k}$ identitetnim afirmacijam posameznih družbenih skupin na lokalni, regionalni, nacionalni in mednarodni ravni ni posledica odprave totalitarnih, kolonialnih in asimilacijskih preprek nacionalnih držav, ampak posledica negotovosti in strahu, ki zaznamujeta svetovno prizorišče, odkar se je kapitalistični sistem ponovno znašel v ciklični krizi. ${ }^{5}$

To, kar se kaže kot družbena izključenost, je dejansko družbena vključenost, le da ta vključenost poteka na podlagi nižjih mezd oziroma na nižjih ravneh ekonomije (črna ekonomija, predkapitalistični načini izkoriščanja), uvajanje ostrejših pogojev izkoriščanja pa se legitimira s partikularistično psihologistično ideologijo. Psihologizem namreč zamaskira strukturne pogoje neenakosti in odgovornost za njen obstoj prelaga na pleča individuov: če so prvi žrtve ene, bojda prirojene naravne in večne značilnosti skupine, ki naj bi ji pripadali, so drugi krivi osebne neodgovornosti in nesposobnosti v kapitalističnem boju (Amin, 2009, 71; Močnik, 2006, 80-82). ${ }^{6}$

\section{Manjšinske pravice kot mehanizem neoliberalnega gospostva}

Ahistorično in esencialistično razumevanje kulture je dalo podlago hkratnemu vstopu Romov $\mathrm{v}$ akademski in politični prostor. Romske skupine se je začelo obravnavati kot kulturno oziroma identitetno in ekonomsko homogeno

4 Globalizacija ni nič novega in je le mit, ki družbene spremembe pod neoliberalno taktirko kaže kot neizbežne (Močnik, 2006, 9-13; Wallerstein, 2006, 34).

5 Zavedamo se, da je naša razlaga izjemno poenostavljena, a njen osnovni namen je predvsem opozoriti na potrebo po »celostnem « pogledu, in sicer tako s prostorskega kakor z družbenega vidika. Za podrobnejšo analizo družbenih transformacij in pojava identitetnih gibanj v drugi polovici 20. stoletja gl. Friedman (2004).

6 Kot lahko beremo v Nacionalnem akcijskem programu zaposlovanja iz leta 2004 (gl. Nacionalni), ki je v popolnem sozvočju z evropsko politiko zaposlovanja in s cilji lizbonske strategije na področju dela in zaposlovanja, "[samozaposlovanje] s širjenjem podjetniške miselnosti in kulture motivira presežne delavce in brezposelne osebe za samoaktiviranje in reševanje lastne brezposelnosti«. 
manjšinsko skupnost, za katero naj bi bile značilne splošna izključenost, revščina in diskriminacija, ki naj bi izhajale iz nepoznavanja njihove kulture, nestrpne okolice ali nezadostne vključenosti $\mathrm{v}$ širšo družbo. Z namenom pridobitve učinkovitih političnih predstavnikov tega, kot ga opredeli Svet Evrope, »evropskega ljudstva indijskega izvora, katerega predniki so zapustili dolino Gangesa na severu Indije pred približno 800 leti [in] ki običajno živi v zelo težkih pogojih in se redno sooča z diskriminacijo« (nav. po Olivera, 2012, 42), se je angažiral niz mednarodnih komisij (Evropska komisija, Svet Evrope), raziskovalnih organizacij (Zavod za odprto družbo, Srednjeevropska univerza v Budimpešti) in finančnih institucij (Svetovna banka, Program Združenih narodov za razvoj), ki sodelujejo z lokalnimi znanstveniki, nevladnimi organizacijami in aktivisti. Njihovo početje je s pomočjo medijev pripomoglo k oblikovanju »romske evropske vulgate«, ki je prispevala h konstrukciji podobe o vsesplošno marginaliziranem prebivalstvu.

A diskurz o Romih kot deprivilegirani ali zatirani manjšini ne vidi svojih notranjih protislovij. Medtem ko sam pojem manjšine zajema kvantitativno maloštevilno skupnost, se prevladujoči diskurz o manjšinah opira na kvalitativni kriterij: ne govori o dejanski družbeni manjšini, se pravi o maloštevilni skupini privilegiranih, ki poseduje kapital in produkcijska sredstva, ampak o številnem in raznolikem prebivalstvu, ki je družbeno skonstruirano v različne etnične, religijske, spolne in druge skupine, ki se jim vnaprej samoumevno določita ekonomska deprivilegiranost in marginalni družbeni položaj. ${ }^{7}$ Še več, predstavniki t. i. manjšine niso obravnavani z gledišča njihovega individualnega položaja, eksistenčnih pogojev in ravnanj, pač pa $z$ vidika zadostitve kriterijem »članstva« v skupini, ki ji je posebna družbena vloga določena »od zunaj« (Glass, 1962, 34-36). Tako ostaja diskurz o večinski oziroma manjšinski skupnosti slep za političnoekonomsko razsežnost problematike. Izrazit primer ohranjanja ali celo povečevanja neenakosti znotraj neke kulturno priznane manjšine pa je nemara prav oblikovanje romske politične elite.

Učinek identitetnega oziroma kulturalističnega diskurza potemtakem ni $\mathrm{v}$ možnosti sobivanja mnoštva identitet, temveč v ignoriranju debate o kapitalizmu in njegovi totalnosti. Kot bomo videli, slovenske študije o Romih, ki nereflektirano sprejemajo postulate, ki jim jih narekujeta manjšinsko pravo in državno-normativni diskurz, pravzaprav posredno legitimirajo vpeljavo neoliberalnih politik, katerih posledice zadevajo vse prebivalce ne glede na njihovo identiteto. Ker so ti procesi predvsem v interesu vladajoče elite, lahko tovrstne študije označimo za državotvorne.

7 Navedimo nekaj podatkov za podkrepitev napisanega: medtem ko je bilo razmerje med najbogatejšimi in najrevnejšimi državami leta $18203: 1$, leta 1973 pa $44: 1$, je leta 1992 naraslo na 72 : 1 . Leta 2004 je približno 0,13 odstotka svetovnega prebivalstva upravljalo s 25 odstotki vsega finančnega bogastva. Leta 2008 pa je 497 najbogatejših (0,000008 odstotka vsega prebivalstva) posedovalo 3,5 trilijona \$ (več kot 7 odstotkov svetovnega BDP) (gl. Shah, 2013). 
Tako raziskave, ki politično opredelitev Romov kot slovenske (homogene) etnične manjšine obravnavajo kot analitsko pertinentno, ostajajo slepe za konstituiranje slovenske nacije na identitetni, kulturni osnovi, obenem pa obstoj (slovenske) nacije obravnavajo kot samoumevnega. S svojim kulturno relativističnim diskurzom ne le perpetuirajo nacionalistično in celo rasno ideologijo, kot ugotavljata Alenka Janko Spreizer (2001, 38-41) in Irena Šumi (Šumi in Janko Spreizer, 2011, 102-107), ampak tudi reificirajo zgodovinski nastanek slovenske države. Nacionalizem in etnicizacija prebivalstva sta legitimirala procese prilaščanja družbenega bogastva s strani domače politično-ekonomske elite, preobrazbo države iz socialne države $\mathrm{v}$ državo kapitala in doseganje gospodarske rasti na plečih prekarnih delavcev. ${ }^{8} \mathrm{Na}$ eni strani namreč diskurz, ki ne kontekstualizira diskriminatornih praks in nacionalističnega hujskanja, ne vidi, da sta etnicizacija in kriminalizacija revščine način legitimiranja reform $\mathrm{v}$ prid uničenja socialne države, ki potekajo sočasno s prekarizacijo delovne sile. ${ }^{9} \mathrm{Na}$ drugi strani pa sta »[r] asizem in netolerantnost, čeprav sta nedostojna slehernega človeka, [...] spontani odgovor ljudstva, ki je zamenjal razredni boj z rasnim bojem« (Breznik, 2005, 140). Etnicizacija skupin tako rešuje eno osnovnih protislovij kapitalizma: hkratnost pravne enakosti in neenakosti v produkcijski sferi (Wallerstein, 2006, 46-56).

Manjšinsko pravo EU se izkaže za priročen pripomoček legitimacije reform, ki jih narekujejo od ljudske volje neodvisne mednarodne finančne in svetovalne organizacije. Zlasti Svet Evrope postsocialističnim državam vzhodne in jugovzhodne Evrope redno grozi z moralističnimi in pokroviteljskimi poročili, ki naj bi dokazovala nespoštovanje človekovih pravic $\mathrm{v}$ teh državah, zaostanke na poti do »civiliziranega in demokratičnega Zahoda«ali »prežitke komunizma«. Ta očitno neskončna »tranzicija» med Balkanom in Evropo na eni strani služi legitimaciji družbenih procesov po razpadu socializma in uveljavljanju neoliberalnih politik kot edinega načina za izhod iz »balkanskega barbarstva «, na drugi strani pa reproducira razmerja centra in periferije znotraj EU (Močnik, 2003, 88-89).

»[N]iso 'Romi' tisti, ki bi potrebovali voluntaristično in usklajeno politiko na evropski ravni. Večina t. i. romskih ali ciganskih skupin je tako na Zahodu kot na Vzhodu na različne načine [...] vključena v svoje okolje« (Olivera, 2012, 46). Družbe namreč niso biljardne krogle, ki se lahko kvečjemu zaletavajo druga v drugo (Baskar, 1998, 295). Pravzaprav bi lahko bile prav antropološke in etnološke študije najboljše protiorožje ahistorizaciji romskih skupin ter primežu manjšinskega prava in kulturnih študijev. A po mnenju Alenke Janko Spreizer (2001,29-46) ostaja slovenska romologija

8 Za medsebojno učinkovanje diskriminacijskih praks, nacionalističnega diskurza in rasti slovenskega gradbenega sektorja gl. Breznik (2005).

9 Za analizo nedavnih sprememb na področju sistema socialnega varstva v Sloveniji gl. Leskošek (2012). 
tematsko in regionalno skoraj nacionalistična ekspertna vednost, saj proučevalci ne problematizirajo svojih metodoloških izhodišč, ki so nekje med folkloristiko in rasizmom, njihovo terensko raziskovanje pa še najbolj spominja na »romologijo na romskih taborih« ali »romologijo na vrtu spominov«. Zato o življenju realnih družbenih akterjev, ki sebe imenujejo na primer Slovensko Roma, vemo zelo malo.

Tako se zdi, da so si zaradi enačenja analitskega govora $\mathrm{z}$ državnim in odsotnosti refleksivnosti prevladujoče študije kljub institucionalnim razlikam in različnim namenom proizvajanja besedil podobne bolj, kakor bi si lahko želeli. Zato bi jih lahko opredelili kot Gypsy Studies oziroma Gypsyology. Medtem ko se prvo poimenovanje nanaša na identitetni diskurz in kulturne študije kot osnovni epistemološki osi teh študij, pa želimo z drugim poimenovanjem poudariti način organiziranja te vednostne produkcije. Raziskovalci so namreč oblikovali »ekskluzivno intelektualno ozemlje«, rezultati katerega drug drugega podpirajo, njihovo početje pa se navzven kaže kot samostojna znanost, kot -logija. ${ }^{10}$ Najboljša potrditev tega je nemara dejstvo, da $\mathrm{v}$ slovenskem prostoru skoraj vsakdo, ki se je kakorkoli ukvarjal z Romi, v očeh javnosti že velja za »poznavalca romskega vprašanja« oziroma za »romologa«.

\section{Emancipacija spoznavnih predmetov in realnih družbenih akterjev}

Kulturni študiji in identitetni diskurz so se pojavili kot odgovor na družbene transformacije, ki zaznamujejo svetovno prizorišče, odkar se je kapitalistični sistem ponovno znašel $\mathrm{v}$ sistemski krizi. K njihovemu prevladujočemu položaju $\mathrm{v}$ družboslovju pa je zagotovo pripomogla tudi močna institucionalna podpora mednarodnih finančnih in političnih organizacij. A videli smo, da tovrstne analize ne le ne zmorejo pojasniti strukturnih vzrokov družbenih sprememb, ampak tudi delujejo proti stališču, ki ga zagovarjajo, saj nevede legitimirajo vzpostavljanje neoliberalne agende. Področje kulturnih študijev in neoliberalna politika se vzajemno dopolnjujeta, saj se njuna diskurza srečata na dveh točkah: skupna sta jima antietatistična drža (saj oba (socialno) državo enačita $\mathrm{z}$ represijo, pa naj gre za izražanje identitet/kultur ali delovanje bojda svobodnega trga) in individualistična ideologija. "Za kulturne partikulariste je akter sleherni med nami (drugačen od vseh drugih), ki vzpostavlja avtonomni diskurz z vsemi drugimi«, pravi Wallerstein $(2006,32)$, medtem ko je glavni akter neoliberalizma odgovorni zasebni agent. Politično tako oba delujeta $\mathrm{v}$ prid slabljenja in delitve delavskega razreda.

10 Alenka Janko Spreizer (2001) tovrstno kritiko namenja predvsem slovenskim antropološkim in etnološkim študijam. Vendar sta nas podrobnejša epistemološka analiza socioloških študij in prepletenost različnih akterjev prepričali, da lahko njeno kritiko apliciramo na širšo vednostno produkcijo o Romih. 
$\mathrm{Z}$ antropološkega vidika so postkolonialni in kulturni študiji zagotovo prebili meje klasične antropologije in njeno razumevanje etnije kot ahistoričnega izolata brez povezav z zunanjim svetom. ${ }^{11}$ Vendar je njihov postulat hibridnosti in popolne osvoboditve slehernih lokalnih kulturnih vezi le negacija prve paradigme, ne pa tudi problematizacija njenih predpostavk in strukturnih določil družbenega delovanja, ki bi raziskovanje pripeljala na teoretsko raven. Obema perspektivama je tako skupno nezgodovinsko razumevanje spoznavnega predmeta, ki ostaja reificirana in izolirana entiteta $-\mathrm{v}$ prvem primeru je izolirana od globalnih, $\mathrm{v}$ drugem pa od lokalnih procesov.

Kvalitativni preobrat družbenih gibanj namreč izvira iz specifičnega konteksta; med drugim je povojni napredek $\mathrm{v}$ državah centra svetovnega sistema omogočil rast srednjega razreda in uveljavitev političnih zahtev sredinskih liberalcev, ki so nasprotovali strukturnim spremembam kapitalističnega sistema, podpirali pa so družbeno-kulturne spremembe. Tako so kolektivne boje proti (imperialni) državi in institucionalnim oblikam represije nadomestili boji za priznanje partikularnih pravic črnske skupnosti, žensk in homoseksualcev - in ne nazadnje Romov.

Naj torej naposled na zastavljeno vprašanje poskusimo odgovoriti recimo takole: če želimo znanstveno početje iztrgati iz primeža samoumevnosti in proučevati realne akterje, moramo analizo prestaviti iz sfere neposredne realnosti v sfero materialnih podlag. Ta poteza je namreč nujna, če želimo retrospektivno razumeti, kakšno vlogo igrajo pojavi iz neposredne realnosti v zgodovinskem procesu in $\mathrm{v}$ tistem, kar je v njem bistveno - v razrednem boju. Izbira konceptualnega aparata historičnega materializma tako ni stvar osebnih preferenc in moralnih načel, temveč je analitsko in politično nujna. Kajti le praksa, ki reflektira pogoje lastnega delovanja, je teoretska, s tem pa tudi emancipatorna.

\section{Literatura}

Amin, S., Evrocentrizem, Ljubljana 2009.

Asséo, H., Gypsy Studies in evropsko manjšinsko pravo, Časopis za kritiko znanosti 39, št. 247, 2012, str. 27-39.

Baskar, B., Antropološka zgodovina, ki je politična antropologija, v: Wolf, E. R., Evropa in ljudstva brez zgodovine, Ljubljana 1998, str. 293-324.

Breznik, M., Umazano delo, umazano ljudstvo, v: Mi in oni: nestrpnost na Slovenskem (ur. Leskošek, V.), Ljubljana 2005, str. 131-148.

Breznik, M., Kultura danajskih darov, Ljubljana 2009.

Centrih, L., Cigo iz Ambrusa, Medijska preža 28, 2007, str. 38.

11 Za raziskovalni preboj kulturnih študijev na področju kulturne produkcije gl. Breznik $(2009,12-14)$. 
Friedman, J., Des racines et (dé)routes, L’homme 156, 2000, str. 187-206.

Friedman, J., Culture et politique de la culture, Anthropologie et Sociétés 28, št. 1, 2004, str. 23-43.

Glass, R., Outsiders-Insiders: The Position of Minorities, New Left Review 17, 1962, str. 34-45.

Janko Spreizer, A., Socialnoantropološki pogled na romologijo v Sloveniji, Monitor ISH 3, št. 1-2, 2001, str. 29-63.

Leskošek, V., Vpliv socialne države na (ne)odvisnost delavcev od tržnih pogojev zaposlovanja, Časopis za kritiko znanosti 39, št. 247, 2012, str. 103-112.

Marx, K., Prispevek h kritiki politične ekonomije. Predgovor, v: Marx, K., Engels, F., Izbrana dela IV, Ljubljana 1979, str. 101-109.

Meiksins Wood, E., Democracy against Capitalism, Cambridge 1995.

Močnik, R., 3 teorije: ideologija, nacija, institucija, Ljubljana 1999.

Močnik, R., Teorija za politiko, Ljubljana 2003.

Močnik, R., Svetovno gospodarstvo in revolucionarna politika, Ljubljana 2006.

Močnik, R., Spisi iz humanistike, Ljubljana 2009.

Nacionalni akcijski program zaposlovanja. Ljubljana 2004, http://www.mddsz.gov. si/fileadmin/mddsz.gov.si/pageuploads/dokumenti_pdf/nap04_05.pdf [14. 3. 2013].

Olivera, M., Strokovna fabrikacija »romskega vprašanja« - prepletenost multikulturalizma in neoliberalizma, Časopis za kritiko znanosti 39, št. 247, 2012, str. $40-48$.

Piasere, L., Les Tsiganes sont-ils »bons à penser« anthropologiquement?, Etudes Tsiganes 2, 1994, str. 19-38.

Shah, A., Poverty Facts and Stats, Global Issues, 7. januar 2013, http://www.globalissues. org/article/26/poverty-facts-and-stats\#src19 [14. 3. 2013].

Šumi, I., Janko Spreizer, A., That Which Soils the Nation's Body: Discriminatory Discourse of Slovenian Academics on the Romany, Foreigners and Women, Anthropological Notebooks 17, št. 3, 2011, str. 101-121.

Wallerstein, I., Uvod v analizo svetovnih-sistemov, Ljubljana 2006. 
Ana Podvršič

\section{On an epistemological choice: Gypsy Studies as a Slovenian nation-building discipline}

Keywords: the Romani people, academic discourse, cultural studies, neoliberalism

Analysing Slovenian sociological production of knowledge about the Romani people, the article problematises the question of epistemological choice in studying social reality. These studies can serve as a case study in examining the complex yet systematised relationship between the changes in social reality and the academic discourse. As an object of inquiry, the Romani people have been introduced in the Slovenian academic discourse after Slovenia's independence and particularly during the period of the accession to the European Union, when Romani people have been granted the status of an ethnic minority. The prevailing studies, which are primarily based in cultural studies, call, together with minority law, for an improvement of the situation of Romani communities, starting with ending discrimination. However, the discourse on the Romani people as an underprivileged minority cannot reflect on the presuppositions of its own practice. Hence, by identifying the normative discourse of the nation-state with the analytical discourse, and by approaching ethnic groups as givens, it works against the very position that it tries to defend; by unknowingly supporting neoliberal policies, it contributes to the reproduction of the existent relations of inequality. 